\title{
Induction and maintenance infliximab therapy in children with moderate to severe ulcerative colitis: Retrospective, multicenter study
}

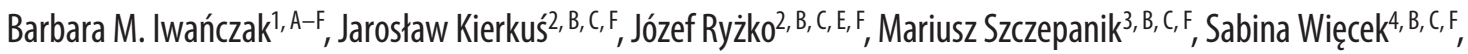

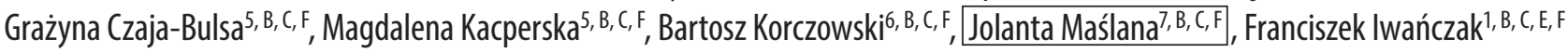 \\ ${ }^{1} 2^{\text {nd }}$ Department of Paediatrics, Gastroenterology and Nutrition, Wroclaw Medical University, Poland \\ ${ }^{2}$ Children's Memorial Health Institute, Warsaw, Poland \\ ${ }^{3}$ Department of Pediatric Gastroenterology and Metabolic Disorders, Poznan University of Medical Science, Poland \\ ${ }^{4}$ Department of Pediatrics, Medical University of Silesia, Gastroenterology Unit, Upper Silesian Child Health Care Center, Katowice, Poland \\ ${ }^{5}$ Pediatric Nursery Unit of Pomeranian Medical University, Division of Pediatrics, Gastroenterology and Reumatology of Zdroje Hospital, Szczecin, Poland \\ ${ }^{6}$ Department of Pediatrics, State Hospital no. 2, Rzeszów, Poland \\ ${ }^{7}$ Province Children's Hospital, Kielce, Poland \\ A - research concept and design; $\mathrm{B}$ - collection and/or assembly of data; $\mathrm{C}$ - data analysis and interpretation; \\ $\mathrm{D}$ - writing the article; $\mathrm{E}$ - critical revision of the article; $\mathrm{F}$ - final approval of article
}

Address for correspondence

Barbara Iwańczak

E-mail: barbara@iwanczak.com

Funding sources

none declared

Conflict of interest

none declared

Received on February 16, 2015

Revised on May 7, 2015

Accepted on May 26, 2015

DOI

10.17219/acem/42197

Copyright

Copyright by Author(s)

This is an article distributed under the terms of the

Creative Commons Attribution Non-Commercial License

(http://creativecommons.org/licenses/by-nc-nd/4.0/)

\begin{abstract}
Background. Pediatric ulcerative colitis (UC) is a severe disease characterised by the presence of extensive inflammatory lesions in the colon. The administration of intravenous corticosteroids is recommended in patients with acute relapse of the disease, whereas early treatment with cyclosporine, tacrolimus or infliximab is recommended if there is no improvement.

Objectives. The aim of this study was to retrospectively evaluate the efficacy and safety of infliximab therapy in the treatment of moderate-to-severe and severe relapse of pediatric UC.

Material and methods. The analysis included 42 children aged 4-18 years ( 23 girls, 19 boys) treated in 7 pediatric gastroenterology departments in Poland during the past 4 years. The disease duration ranged from 2 to 100 months. The clinical activity of UC ranged from 35 to 85 points according to the PUCAI scale. Twenty-one children were diagnosed with pancolitis, 10 children with extensive UC, and the remaining with the left-sided UC. In the induction therapy infliximab was administered at doses of $5 \mathrm{mg} / \mathrm{kg}$ in the 0.2 and 6 weeks, and after the clinical response every 8 weeks to 12 months. Treatment results were assessed in 10 and 54 weeks.
\end{abstract}

Results. After the induction therapy the clinical response was achieved in 14 children (33.33\%) and clinical remission in 11 children (26.19\%). Two children required surgical treatment, and the remaining 2 suffered from anaphylactic shock. After the maintenance therapy clinical remission was maintained in 12 children (57.14\%), whereas 3 children required surgery (colectomy).

Conclusions. Infliximab therapy in children with moderate-to-severe UC induces remission and, in some children, proves to be effective in preventing early colectomy.

Key words: children, infliximab, ulcerative colitis 
Ulcerative colitis (UC) is a chronic, non-specific inflammatory bowel disease of unknown etiology. Disease etiopathogenesis involves genetic, environmental and immunological factors. The impaired interaction between these factors results in the excessive production of inflammatory cytokines, including tumor necrosis factor- $\alpha$ (TNFalpha). Rectal bleeding, bloody diarrhea, abdominal pain and weight loss dominate the clinical picture of this disease. Laboratory studies confirmed elevated calprotectin concentrations, accelerated erythrocyte sedimentation reaction, elevated concentration of C-reactive protein, anemia and other biochemical disorders. The course of the disease is chronic, with periods of exacerbations and remissions. Clinical studies highlight the differences of the activity and the extent of lesions in the large intestine in children and adults. Children present more acute course of UC, and even at the disease onset inflammatory lesions in the mucous membrane involve the entire colon. ${ }^{1-5}$ It should be emphasized that the severe relapse of the disease in children poses a risk of serious complications like the gastrointestinal perforation, toxic megacolon (megacolon toxicum), and infectious complications. ${ }^{6-9}$

$\mathrm{UC}$ treatment depends on the disease activity and the endoscopic assessment of the extent of inflammatory lesions. Turner et al.in 2007 proposed to assess the severity of relapses in children on the basis of the non-invasive point scale based on the disease symptoms (Pediatric Ulcerative Colitis Activity Index - PUCAI).${ }^{10}$ The treatment includes glucocorticoids, 5-ASA preparations, immunomodulators, antibiotics, and surgical treatment. The administration of biological drugs was introduced in patients who had not responded to conventional therapies. ${ }^{7,9,11,12}$ Monoclonal antibodies targeting TNF-alpha: infliximab, adalimubab, and golimubab have been approved by the US Food and Drug Administration for the treatment of UC in adults. Infliximab has also been registered in the EU for the treatment of moderate-to-severe UC. In Poland, infliximab has been approved for the treatment of severe UC in adults and children aged 6-17 years, in patients who do not respond to standard therapies or those who poorly tolerate them.

\section{Objectives}

The aim of this study was to retrospectively evaluate the efficacy and safety of infliximab therapy in moderatesevere and severe relapses of pediatric UC.

\section{Material and methods}

The analysis included 42 children aged 4-18 years (23 girls and 19 boys) treated in 7 regional pediatric gastroenterology departments in Poland, with moderate or severe relapses of UC. Two children were under 5 years, 5 children 6-10 years old, other children $11-18$ years old
Table 1. Characteristics of children with ulcerative colitis treated with infliximab

\begin{tabular}{|c|c|c|}
\hline \multirow{2}{*}{ Assessed parameter } & \multicolumn{2}{|c|}{ Number of children } \\
\hline & $\mathrm{n}$ & $\%$ \\
\hline $\begin{array}{l}\text { Sex: male } \\
\text { female }\end{array}$ & $\begin{array}{l}19 \\
23\end{array}$ & $\begin{array}{l}45.24 \\
54.76\end{array}$ \\
\hline $\begin{array}{l}\text { Age (years): }<5 \\
\quad 6-10 \\
11-18\end{array}$ & $\begin{array}{r}2 \\
5 \\
35\end{array}$ & $\begin{array}{r}4.77 \\
11.90 \\
83.33\end{array}$ \\
\hline $\begin{array}{l}\text { Age at diagnosis (years): }<5 \\
6-10 \\
11-17\end{array}$ & $\begin{array}{r}6 \\
14 \\
22\end{array}$ & $\begin{array}{l}14.29 \\
33.33 \\
52.38\end{array}$ \\
\hline IBD in family: & $\begin{array}{c}1 \\
\text { (mother - UC) }\end{array}$ & 2.38 \\
\hline Concomitant disorders & 4 & 9.52 \\
\hline Extraintestinal symptoms & 16 & 38.09 \\
\hline
\end{tabular}

(Table 1). Children below 6 years of age obtained an agreement from the Bioethical Committee for non-conventional therapy. The diagnosis of UC has been established on the basis of symptoms, lab test results, and endoscopic examination in accordance with the Porto criteria. ${ }^{13}$ In 6 children (14.29\%) the disease was diagnosed between $2-5$ years of age, in 14 patients (33.33\%) between 6-10 years of age, in 22 children $(52.38 \%)$ between $11-17$ years of age. The duration of the disease ranged from 2 to 100 months. For 3 children this was the first acute relapse of the disease, the remaining children had already had from 2 to 8 relapses. Four children were diagnosed with other diseases such as celiac disease, diabetes, hypertension, and kidney stones. Parenteral symptoms such as joint pain, erythema nodosum, anemia, osteoporosis, and deep vein thrombosis have been observed in 16 children (38.09\%). One child suffered from pyoderma gangrenosum; the mother of one child was diagnosed with UC. The clinical activity of the disease was assessed according to PUCAI scale developed by Turner et al. with the following symptoms: abdominal pain, rectal bleeding, stool consistency, the number of stools, nocturnal stools, activity level. ${ }^{10}$ The PUCAI score ranging from 65 to 85 points indicated the severe relapse of the disease, 35-64 points moderate relapse, 1034 points mild relapse. Scores of $<10$ points indicated inactive disease, in clinical remission. ${ }^{10}$ The location and the extent of large bowel lesions in children during endoscopic examination were assessed based on Paris classification, developed by Levinea et al. in 2011. ${ }^{14}$ According to this classification, ulcerative proctitis (proctitis), left-sided inflammation (distal to splenic flexure), extensive (distal to hepatic flexure), and pancolitis have been distinguished. The location of inflammation based on the endoscopic examination has been presented in Table 2. Twenty-one children $(50.0 \%)$ were diagnosed with pancolitis, 10 children $(23.81 \%)$ had extensive lesions in the colon, while the remaining 11 children (26.29\%) had left-sided location of the disease. 
Table 2. Location of ulcerative colitis in 42 children treated with infliximab

\begin{tabular}{|c|c|c|c|c|c|c|c|c|}
\hline \multirow{3}{*}{ Age (years) } & \multicolumn{8}{|c|}{ Location of ulcerative colitis } \\
\hline & \multicolumn{2}{|c|}{ left sided } & \multicolumn{2}{|c|}{ extensive } & \multicolumn{2}{|c|}{ pancolitis } & \multicolumn{2}{|c|}{ total } \\
\hline & $\mathrm{n}$ & $\%$ & $\mathrm{n}$ & $\%$ & $\mathrm{n}$ & $\%$ & $\mathrm{n}$ & $\%$ \\
\hline$<5$ & 0 & & 0 & & 2 & 4.77 & 2 & 4.77 \\
\hline $6-10$ & 2 & 4.77 & 1 & 2.38 & 2 & 4.77 & 5 & 11.90 \\
\hline $11-17$ & 9 & 21.43 & 9 & 21.43 & 17 & 40.76 & 35 & 83.33 \\
\hline Total & 11 & 26.19 & 10 & 23.81 & 21 & 50.00 & 42 & 100.00 \\
\hline
\end{tabular}

Before infliximab therapy, all patients were unsuccessfully treated with corticosteroids, 5-ASA preparations, azathioprine (38 children), metotreksat (3 children), 6-mercaptopurine (1 child), tacrolimus (1 child), and cyclosporine (22 children). Steroid resistance or steroiddependency occurred in 27 children. Infliximab was administered by intravenous infusion at doses of $5 \mathrm{mg} / \mathrm{kg}$ in 0.2 and 6 weeks, and after clinical response from 8 weeks to 12 months. The reduction of PUCAI scores by at least 20 points indicated clinical response, the reduction by 10 points indicated clinical remission. The results of UC treatment with infliximab were assessed in 10 and 54 weeks of treatment. The evaluation of clinical activity of the disease after induction and maintenance therapy was subjected to statistical analysis using Student's t-test (STATISTICA PL10).

\section{Results}

Table 3, demonstrates the results of induction infliximab therapy in 42 children with ulcerative colitis. Clini- cal response following induction therapy with infliximab was achieved in 14 children (33.33\%), and clinical remission in 11 children (26.19\%). In 15 children (35.72\%) there was no improvement after treatment with infliximab, after the second dose of an intravenous injection of infliximab anaphylactic shock occurred in 2 patients. Apart from that, no other adverse events were observed during induction and maintenance therapy. In 2 children a severe condition, megacolon toxicum, required surgery (colectomy). Table 4 demonstrates the results of induction and maintenance treatment with infliximab in 21 children. In 12 children (57.14\%) clinical remission which lasted for 24 months was still sustained, 9 children suffered from exacerbations during or after treatment. There was no significant difference in the outcome depending on the location of the disease. In 3 children a colectomy was performed because it was a life-threatening condition for the patients. Table 5, which demonstrates the results of clinical disease activity assessed by PUCAI score, showed a statistically significant decrease in the activity of the disease after induction therapy, as well as the maintenance therapy.

Table 3. The results of induction infliximab therapy in 42 children with ulcerative colitis

\begin{tabular}{|c|c|c|c|c|c|c|c|c|}
\hline \multirow{3}{*}{ Clinical assessment } & \multicolumn{8}{|c|}{ Location of ulcerative colitis } \\
\hline & \multicolumn{2}{|c|}{ left sided } & \multicolumn{2}{|c|}{ extensive } & \multicolumn{2}{|c|}{ pancolitis } & \multicolumn{2}{|c|}{ total } \\
\hline & $\mathrm{n}$ & $\%$ & $\mathrm{n}$ & $\%$ & $\mathrm{n}$ & $\%$ & $\mathrm{n}$ & $\%$ \\
\hline Clinical response & 3 & 27.27 & 4 & 40.00 & 7 & 53.33 & 14 & 33.33 \\
\hline Clinical remission & 4 & 36.36 & 2 & 20.00 & 5 & 23.81 & 11 & 26.19 \\
\hline Lack of response & 3 & 27.27 & 4 & 40.00 & 8 & 38.10 & 15 & 35.72 \\
\hline Anaphylactic shock & 1 & 9.10 & 0 & & 1 & 4.76 & 2 & 4.76 \\
\hline Total & 11 & 100.00 & 10 & 100.00 & 21 & 100.00 & 42 & 100.00 \\
\hline
\end{tabular}

Table 4. The results of induction and maintenance infliximab therapy in 21 children with ulcerative colitis

\begin{tabular}{|c|c|c|c|c|c|c|c|c|}
\hline \multirow{3}{*}{ Clinical assessment } & \multicolumn{8}{|c|}{ Location of ulcerative colitis } \\
\hline & \multicolumn{2}{|c|}{ left sided } & \multicolumn{2}{|c|}{ extensive } & \multicolumn{2}{|c|}{ pancolitis } & \multicolumn{2}{|c|}{ total } \\
\hline & $\mathrm{n}$ & $\%$ & $\mathrm{n}$ & $\%$ & $\mathrm{n}$ & $\%$ & $\mathrm{n}$ & $\%$ \\
\hline Clinical remission & 3 & 60.0 & 3 & 60.0 & 6 & 54.55 & 12 & 57.14 \\
\hline Exacerbants during or after treatment & 2 & 40.0 & 2 & 40.0 & 2 & 18.18 & 6 & 28.57 \\
\hline Surgical treatment & - & & - & & 3 & 27.27 & 3 & 14.29 \\
\hline Total & 5 & 100.0 & 5 & 100.0 & 11 & 100.0 & 21 & 100.0 \\
\hline
\end{tabular}


Table 5. A comparison of clinical activity UC before and after induction and maintenance infliximab therapy

\begin{tabular}{|c|c|c|c|c|c|c|c|c|c|c|}
\hline \multirow{3}{*}{ Infliximab therapy } & \multirow{3}{*}{$\begin{array}{l}\text { Number } \\
\text { of children }\end{array}$} & \multicolumn{9}{|c|}{ Clinical activity UC (PUCAI) } \\
\hline & & \multicolumn{4}{|c|}{ before treatment } & \multicolumn{5}{|c|}{ after treatment } \\
\hline & & mean & SD & median & from-till & mean & SD & median & from-till & $\mathrm{p}$ \\
\hline Induction infliximab theraphy & 40 & 58.69 & 16.82 & 65 & $35-85$ & 23.0 & 23.25 & 15 & $0-75$ & $<0.001$ \\
\hline $\begin{array}{l}\text { Induction and maintenance } \\
\text { infliximab therapy }\end{array}$ & 21 & 58.52 & 16.41 & 60 & $35-85$ & 20.0 & 25.83 & 5 & $0-75$ & $<0.001$ \\
\hline
\end{tabular}

\section{Discussion}

The natural course of pediatric UC is characterized by its severe course and by the extensive inflammatory lesions in the large intestine mucosa. According to Griffiths, UC develops in children and adolescents in $25 \%$ of cases. ${ }^{1}$ In children, the disease varies in its clinical activity from mild to severe, with multiple exacerbations. With its onset in early childhood, the disease is characterized by a severe clinical course and numerous acute relapses. Hyams et al., in their studies, reported that $57 \%$ of 171 children with newly diagnosed colitis had a moderate-to-severe form of the disease and the remaining children had its mild form. ${ }^{15}$ According to van Limbergen et al., extensive inflammatory changes occur in $82 \%$ of children compared to $48 \%$ of adults. ${ }^{4}$ In contrast, ulcerative proctitisis presents in $1.4 \%$ of children compared to $17 \%$ of adults, left sided colitis in $16.4 \%$ of children compared to $35 \%$ of adults. The risk of severe acute relapses in adults is lower, ranging from $15 \%$ to $25 \% .{ }^{4}$ In our study extensive inflammatory changes and pancolitis in $73.81 \%$ of children were observed. Only in $26.19 \%$ of children left sided colitis was present.

UC treatment depends on the activity of its relapses. Corticosteroids, 5-ASA preparations, immunomodulators, and antibiotics are used in the treatment of moderate-to-severe pediatric UC, and in the case of no improvement, surgery (colectomy) is recommended., ${ }^{3,7,12}$ Recently, infliximab has been introduced in the treatment of UC in adults and children and its effectiveness has been proven in the induction and maintenance of the clinical remission, and in reducing the use of steroids and surgery (colectomy). ${ }^{8,16-19}$ Cucchiara et al., in a retrospective, multicenter study, confirmed the efficacy of infliximab in the treatment of the active pediatric $\mathrm{UC} .^{20}$ According to the authors, 55\% of the children responded clinically to the treatment. Hyams et al. confirmed the efficacy and safety of infliximab in the treatment of moderate-to-severe pediatric UC. ${ }^{21}$ After the induction, clinical response was induced in $73.3 \%$ of patients, and $28.6 \%$ of children were in clinical remission in the $54^{\text {th }}$ week. Szychta et al. in 2012 presented the results of the first in Poland infliximab therapy of severe pediatric UC. ${ }^{22}$ According to the authors, clinical response was achieved only in 2 patients. Meanwhile, the remaining patients did not respond to infliximab induction therapy. Four children required surgical treatment. One pa- tient suffered from severe anaphylaxis after having been given the drug.

In this study, after the infliximab induction therapy, the authors obtained a clinical response and clinical remission of the disease in 25 children (59.52\%). Two children required surgical treatment. However, maintenance treatment carried out in 21 children induced clinical remission in 12 of them (57.14\%). Re-administration of glucocorticoids, cyclosporine, or adalimumab was necessary in other children, whereas 3 children required surgery (colectomy). Infliximab appeared to be generally a safe drug. Anaphylactic shock occurred in 2 children after the administration of the second dose.

Response to treatment and clinical remission of the disease were reported in more than $50 \%$ of children who had not responded to standard treatment of moderate-tosevere and severe UC. Therefore, in severe cases of UC, infliximab therapy may be an important attempt in treating UC before surgical treatment. Successful infliximab therapy reduces the number of hospitalized children and the number of early colectomies. Infliximab was safe and well-tolerated in most patients.

\section{References}

1. Griffiths AM. Specificites of inflammatory bowel disease in childhood. Best Pract Res Clin Gastroenterol. 2004;18:509-523.

2. Ryżko J, Bartnik W, Socha P, Czubkowski P. Odrębności kliniczne nieswoistych zapaleń jelit u dzieci. Pediatr Pol. 2003;78:355-361.

3. Turner D, Griffiths AM. Acute severe ulcerative colitis in children: A systematic review. Inflamm Bowel Dis. 2011;17:440-449.

4. Van Limbergen J, Russell RK, Drummond HE, et al. Definition of phenotypic characteristics of childhood-onset inflammatory bowel disease. Gastroenterology. 2008;135:1114-1122.

5. Dotson JL, Hyams JS, Markowitz J, et al. Extraintestinal manifestations of pediatric inflammatory bowel disease and their relation to disease type and severity. J Pediatr Gastroenterol Nutr. 2010;51:140-145.

6. Benchimol El, Turner D, Mann EH, et al. Toxic megacolon in children with inflamatory bowel disease: Clinical and radiographic characteristics. Am J Gastroenterol. 2008;103:1524-1531.

7. Turner D, Simon PL, Travis SP, et al. Consensus for managing acute severe ulcerative colitis in children: A systematic review and joint statement from ECCO, ESPGHAN, and the Porto IBD Working Group of ESPGHAN. Am J Gastroenterol. 2011;106:574-588.

8. Turner D, Mack D, Leleiko N, et al. Severe pediatric ulcerative colitis: A prospective multicenter study of outcomes and predictors of response. Gastroenterology. 2010;138:2282-2291.

9. Iwańczak B, Iwańczak F. Leczenie ciężkiego ostrego rzutu wrzodziejącego zapalenia jelita grubego u dzieci. Pediatr Współcz Gastroenterol Hepatol Żywienie Dziecka. 2011;13:175-179.

10. Turner D, Otley AR, Mack D, et al. Development, validation, and evaluation of a pediatric ulcerative colitis activity index: A prospective multicenter study. Gastroenterol. 2007;133:423-432. 
11. Ford AC, Khan KJ, Sandborn WJ, Hanauer SB, Moayyedi P. Efficacy of biological therapies in inflammatory bowel disease: Systemic review and meta-analysis. Am J Gastroenterol. 2011;106:644-659.

12. Turner D, Walsh CM, Benchimol El, et al. Severe paediatric ulcerative colitis: Incidence, outcomes and optimal timing for secondline therapy. Gut 2008;57:331-338.

13. IBD Working Group of the European Society for Paediatric Gastroenterology Hepatology and Nutrition. Inflammatory bowel disease in children and adolescents: Recommendations for diagnosis - the Porto criteria. J Pediatr Gastroenterol Nutr. 2005;41:1-7.

14. Levine A, Griffiths A, Markowitz J, et al. Pediatric modification on the Montreal classification of inflammatory bowel disease: The Paris classification. Inflamm Bowel Dis. 2011;17:1314-1321.

15. Hyams JS, Davis $P$, Grancher $K$, Lerer T, Justinich CJ, Markowitz J. Clinical outcome of ulcerative colitis in children. J Pediatr. 1996;129:81-88.

16. Turner D, Walsh CM, Steinhart AH, Griffiths AM. Response to corticosteroids in severe ulcerative colitis: A systematic review of the literature and a meta-regression. Clin Gastroenterol Hepatol. 2007;5:103-110.
17. Rutgeerts P, Sandborn WJ, Feagan BG, et al. Infliximab for induction and maintenance therapy for ulcerative colitis. $N$ Engl J Med. 2005;353:2462-2476.

18. Sylvester FA, Turner D, Draghi A $2^{\text {nd }}$, et al. Fecal osteoprotegerin may guide the introduction of second-line therapy in hospitalized children with ulcerative colitis. Inflamm Bowel Dis. 2011;17:1726-1730.

19. Järnerot G, Hertervig E, Friis-Liby I, et al. Infliximab as rescue therapy in severe to moderately severe ulcerative colitis: A randomized, placebo-controlled study. Gastroenterol. 2005;128:1805-1811.

20. Cucchiara S, Romeo E, Viola F, et al. Infliximab for pediatric ulcerative colitis: A retrospective Italian multicenter study. Dig Liver Dis. 2008;40:260-264.

21. Hyams J, Damaraju L, Blank M, et al. T72 Study Group. Induction and maintenance therapy with infliximab for children with moderate to severe ulcerative colitis. Clin Gastroenterol Hepatol. 2012;10:391-399.

22. Szychta M, Kierkuś J, Dądalski M, Wegner A, Kmiotek J, Ryżko J. Leczenie biologiczne infliksymabem ciężkiej postaci wrzodziejącego zapalenia jelita grubego u dzieci. Pediatr Współcz Gastroenterol Hepatol Zywienie Dziecka. 2012;14:83-87. 